\title{
Evaluation of reduction in egg shedding of gastrointestinal nematodes in cattle following administration of anthelmintics
}

\author{
Avaliação na redução de ovos de nematódeos gastrintestinais \\ em bovinos após a administração de anti-helmínticos
}

\author{
Ricardo Velludo Gomes de Soutello ${ }^{1 *}$; Wilian Marinho Dourado Coelho ${ }^{1}$; Fernando Paes de Oliveira ${ }^{1}$; \\ José Francisco Fonzar ${ }^{1}$; Brenda Carla Luquetti ${ }^{1}$; Renata Furlan Pereira de Souza ${ }^{1}$; \\ Maria Conceição Zocoller Seno ${ }^{2}$; Alessandro Francisco Talamini do Amarante ${ }^{3}$ \\ ${ }^{1}$ Curso de Medicina Veterinária, Faculdade de Ciências Agrárias de Andradina - FCAA \\ ${ }^{2}$ Universidade Estadual Paulista - UNESP \\ ${ }^{3}$ Departamento de Parasitologia, Instituto de Biociências, Universidade Estadual Paulista - UNESP
}

Received September 24, 2009

Accepted June 15, 2010

\begin{abstract}
To evaluate the necessary time and to identify the differences among anthelmintics for the reduction of parasite eggs shed in feces, five groups of cattle were treated with moxidectin, ivermectin, levamisole phosphate, and albendazole sulphoxide. Levamisole promoted a reduction in egg count per gram (EPG-R) of $97.4 \%$ after 24 hours, moxidectin $98.3 \%$ after 36 hours, and albendazole sulphoxide $95.9 \%$ after 36 hours post- treatment. Cooperia spp. and Haemonchus spp. showed resistance to ivermectin. The results demonstrated that the diagnosis of parasite resistance in cattle can be based on a count of eggs per gram (EPG) carried out as soon as seven days after the treatment.
\end{abstract}

Keywords: Anthelmintic, cattle, resistance, Cooperia, Haemonchus.

\section{Resumo}

No intuito de avaliar o tempo necessário para redução dos valores de OPG visando identificar o início de atuação dos anti-helmínticos, cinco grupos de novilhos, naturalmente infectados por nematódeos gastrintestinais foram tratados com moxidectina, ivermectina, fosfato de levamisol e sulfóxido de albendazol. O levamisol promoveu redução no número de ovos de nematódeos eliminados nas fezes (R-OPG) de 97,4\% 24 horas após a aplicação, a moxidectina de 98,3\% após 36 horas, e o sulfóxido de albendazol de 95,9\% após 36 horas. Foi registrada a presença de Cooperia spp. e Haemonchus spp. com resistência a ivermectina. A contagem de OPG realizada aos sete dias pós-tratamento apresentou resultados similares aos obtidos nas contagens realizadas 10 e 14 dias após a aplicação dos anti-helmínticos avaliados, demonstrando que o intervalo adequado entre o tratamento anti-helmíntico e o exame para verificar a reduçáo do OPG pode ser de 7 dias.

Palavras-chaves: Anti-helmínticos, bovinos, resistência, Cooperia, Haemonchus.

\section{Introduction}

The widespread use of anthelmintics in cattle has led to the emergence of parasite-resistant populations (PAIVA et al., 2001; SOUZA et al., 2008; WOLSTENHOLME et al., 2004). This fact is confirmed by testing the reduction in the number of nematode eggs in feces, as there is a correlation between the number of eggs per gram (EPG) and worm burden in cattle (BRYAN; KERR, 1989). However, the ideal time between treatment and feces collection for EPG monitoring to accurately verify the effectiveness of anthelmintics is still a matter of debate.

\footnotetext{
*Corresponding author: Ricardo Velludo Gomes de Soutello Curso de Medicina Veterinária,

Faculdade de Ciências Agrárias de Andradina - FCAA,

Rua Amazonas, 571, CEP 16901-160, Andradina - SP, Brazil;

e-mail: soutello@fea.br
}

This study aimed to evaluate the efficacy of several classes of anthelmintics in cattle naturally infected with gastrointestinal nematodes. We assessed the time required to decrease levels of EPG after treatment and indicated the most appropriate period for collecting fecal samples for studies of parasite resistance.

\section{Material and Methods}

We used 24 male crossbred calves, aged 12 months and kept in paddocks of Brachiaria decumbens. Fecal EPG were determined for each animal according to Gordon et al. (1939). Animals were divided into five lots (four treatment groups and one control group) according to the obtained values. Coprocultures were performed 
on days 7, 14, and 28 after treatment (ROBERTS; O'SULLIVAN, 1950) and larvae were identified according to Keith (1953).

We administered the following anthelmintics subcutaneously at the doses recommended by the manufacturers: albendazole sulfoxide 15\% (3.75 mg. $\mathrm{kg}^{-1}$; Ricobendazole ${ }^{\varpi}$, Fort Dodge), levamisole phosphate $18.8 \%$ (4.7 mg. $\mathrm{kg}^{-1}$; Ripercol ${ }^{\circledast}$, Fort Dodge), $1 \%$ moxidectin (0.2 mg. $\mathrm{kg}^{-1}$; Cydectin ${ }^{\oplus}$, Fort Dodge), and $1 \%$ ivermectin (0.2 mg. $\mathrm{kg}^{-1}$; Ivomec ${ }^{\ominus}$, Merial), and the control group without treatment. All groups consisted of five animals except for the moxidectin-treated group, which consisted of four.

EPG fecal tests were performed 4, 8, 12, 18, 24, 36, and 48 hours later, every 24 hours for 12 days, and subsequently every other day (48 hours) for more than 14 days until the end of the experiment (28 days). Reduction of EPG (R-EPG) counting for all groups was determined by calculating the arithmetic mean obtained by comparing the initial and post-treatment EPG count, for each anthelmintic, and also by using the program RESO (COLES et al., 1992).

\section{Results and Discussion}

Reduction of EPG counts was rapidly observed after the administration of all anthelmintics. Two days after treatment, all groups except the ivermectin-treated group showed EPG mean equal to zero. EPG mean obtained from the treated groups showed little variation between 4 and 14 days post-treatment (Figure 1). Similar results were observed for the combination of ivermectin $2.25+1.25 \%$ abamectin in cattle, with no significant difference reported between the EPG-R of 7 and 13 days post-treatment (NASCIMENTO et al., 2003). Willians et al. (1997) observed mean values close to zero between 7 and 15 days post-treatment.

Coprocultures carried out on days zero, 7, 14, and 28 post-treatment showed that at day zero, animals of all groups had mixed infection with a predominance of Cooperia (above 70\%), followed by Haemonchus and Oesophagostomum, both of which continued to be identified in subsequent coprocultures. Larvae were not identified in coprocultures after treatment with moxidectin. Cooperia larvae were found in the group treated with albendazole and levamisole, while the group treated with ivermectin showed predominance of Cooperia followed by the genus Haemonchus.

Effective action was determined when EPG-R was superior than 95\%. When EPG-R mean values of each group were compared with its respective EPG mean initial values, we observed that levamisole promoted EPG-R of $97.4 \%$ in 24 hours, moxidectin $97.9 \%$ in 36 hours, and albendazole sulfoxide $95.9 \%$ in 36 hours. Ivermectin showed limited effectiveness during the experiment, with the greatest reduction $(72.2 \%)$ after treatment observed at 72 hours.

When the EPG-R mean values were compared with the mean values obtained for the control group, we observed similar results. Three days after treatment with albendazole, levamisole, and moxidectin EPG-R was $100 \%$, and persisted until the end of the experiment in the case of moxidectin. Eggs were detected again in the group treated with albendazole after 20 days while with levamisole they were detected at 7, 22, 26, and 28 days post-treatment. The EPG-R (RESO) at 4, 7, 10 and 14 days after treatment with ivermectin was respectively $77,71,91$ and $76 \%$. The value variation occurred in relation to changes in the EPG values of the control group.

Taylor et al. (2002) suggested that sampling for EPG monitoring should be done about 10 to 14 days after anthelmintic treatment, except in cases of suspected resistance to levamisole in which case samples should be collected 7 days after treatment. However, this study shows that the EPG count realized 7 days after treatment showed results similar to EPG counting performed between 10 and 14 days. The work shows that the appropriate interval to confirm the EPG-R may be 7 days or less, and that adopting such a procedure could facilitate management.

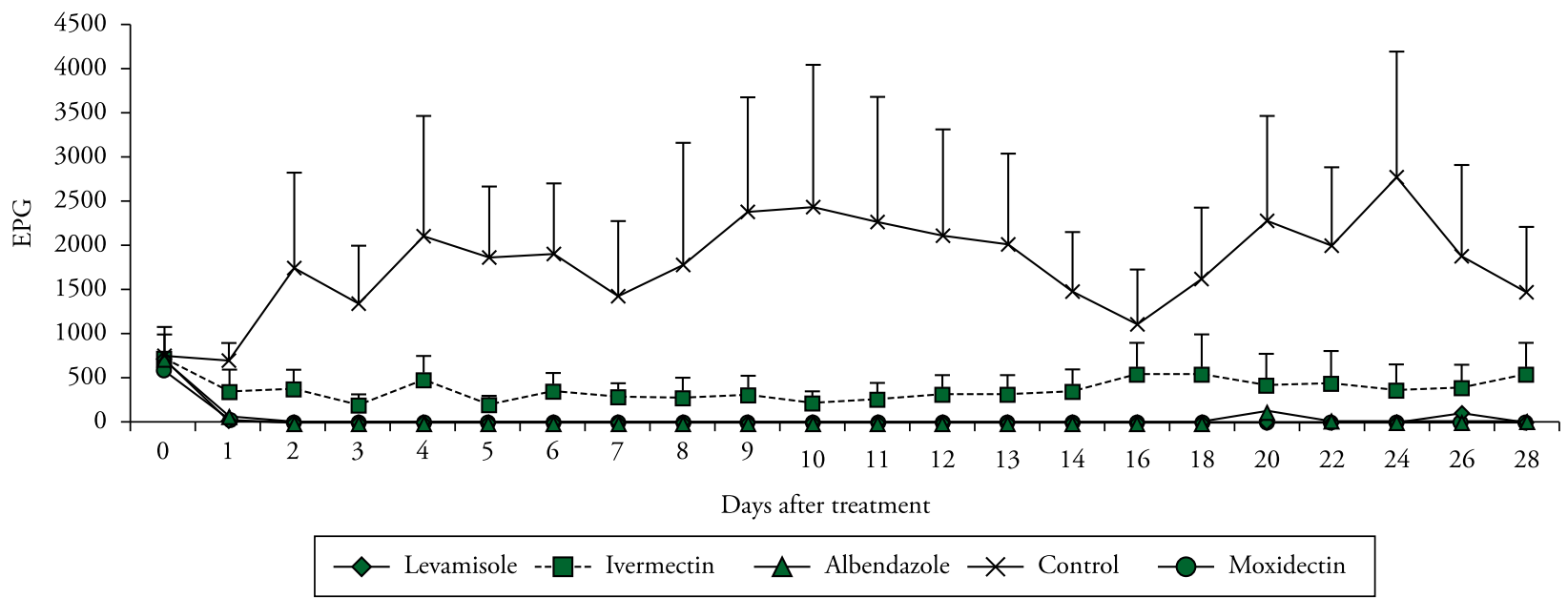

Figure 1. Average score of gastrointestinal nematode eggs (EPG) in groups of cattle treated with anthelmintics and in the control group (untreated), over 28 days after administration of four anthelmintics. Bar = standard error. 


\section{References}

BRYAN, R. P.; KERR, J. D. The relationship between the natural worm burden of steers and the faecal egg count differentiated to species. Veterinary Parasitology, v. 30, n. 4, p. 327-334, 1989.

COLES, G. C. et al. World Association for the Advancement of Veterinary Parasitology (W.A.A.V.P.) methods for the detection of anthelmintic resistance in nematodes of veterinary importance. Veterinary Parasitology, v. 44, n. 1-2, p. 35-44, 1992.

GORDON, H. M.; WHITLOCK, H. V. A new technique for counting nematode eggs in sheep faeces. Journal of Scientific and Industrial Research, v. 12, p. 50-52, 1939.

KEITH, R. K. The differentiation of the infective larvae of some common nematode parasites of cattle. Australian Journal of Zoology, v. 1, n. 2, p. 223-235, 1953.

NASCIMENTO, A. A. et al. Atividade anti-helmíntica de uma nova formulação de longa ação contendo ivermectina $2,25 \%$ + abamectina $1,25 \%$, no tratamento de bovinos naturalmente infectados por nematódeos parasitas. A Hora Veterinária, n. 5, p. 33-36, 2003. Edição extra.
PAIVA, F. et al. Resistência a ivermectina constatada em Haemonchus placei e Cooperia punctata em bovinos. A Hora Veterinária, n. 120, p. 29-32, 2001.

ROBERTS, F. H. S.; O'SULLIVAN, P. J. Methods for egg counts and larval cultures for strongyles infecting the gastro-intestinal tract of cattle. Australian Journal of Agricultural Research, v.1, p. 99-102, 1950.

SOUZA, A. P. et al. Resistência de helmintos gastrintestinais de bovinos a anti-helmínticos no planalto Catarinense. Ciência Rural, v. 38, n. 5, p. 1363-1367, 2008.

TAYLOR, M. A.; HUNT, K. R.; GOODYEAR, K. L. Anthelmintic resistance detection methods. Veterinary Parasitology, v. 103, n. 1-2, p. 183-194, 2002.

WILLIANS, J. C. et al. Comparative efficiency of ivermectin pour-on, albendazole, oxfendazole e fenbendazole against Ostertagia ostertagi inhibited larvae, other gastrointestinal nematodes and lungworm of cattle. Veterinary Parasitology, v. 73, n. 1-2, p. 73-82, 1997.

WOLSTENHOLME, A. J. et al. Drug resistance in veterinary helminthes. Trends in Parasitology, v. 20, n. 10, p. 469-476, 2004. 